\title{
Experimental model in hamster \\ (Mesocricetus auratus) to study heterologous \\ graft of scars and cutaneous diseases in plastic \\ surgery ${ }^{1}$
}

\author{
Bernardo Hochman ${ }^{2}$ \\ Lydia Masako Ferreira ${ }^{3}$ \\ Flaviane Cássia Vilas Bôas ${ }^{4}$ \\ Mario Mariano ${ }^{5}$
}

\begin{abstract}
Hochman B, Ferreira LM, Vilas Bôas FC, Mariano M. Experimental model in hamster (Mesocricetus auratus) to study heterologous graft of scars and cutaneous diseases in plastic surgery. Acta Cir Bras [serial online] 2004 Vol 19 Special Edition. Available on URL: http://www.scielo.br/acb.

ABSTRACT: Syrian golden hamster (Mesocricetus auratus) has in its cheek pouches sub-epithelium an "Immunologically Privileged Site" which allows the integration of homo- and heterologous graft. This paper describes some anatomical and histological characteristics of that site, as well as analyzes aspects related with its immune properties. It also focuses the advantages of this experimental model over other models which are natural or induced carriers of immunodeficiency. Based on both these advantages and literature, this study aims to establish this model, through the performance of heterologous graft, as another option for the investigation of scar disturbances, as keloids and other diseases which may interest Plastic Surgery, as benign cutaneous lesions, and malignant neoplasias such as skin carcinomas and melanomas. The work also addresses perspectives for using this model, which still is a source scarcely known by Brazilian medical class.
\end{abstract}

KEY WORDS: Mesocricetus. Transplantation, heterologous. Skin transplantation. Keloid.

\section{Introduction}

Technological advances in the area of genetic Bioengineering allowed the creation of experimental models, mutant and isogenic mice and rats which are deficient in $\mathrm{T}$ and $\mathrm{B}$ cells, $\mathrm{K}$ (Killer) cells, and NK (Natural Killer) cells, or even with congenital absence of thymus.

\footnotetext{
This paper is a part of a Thesis presented to Federal University of São Paulo-Paulista School of Medicine in 2002 by the Post-Graduation Program of Recovering Plastic Surgery (UNIFESP-EPM), to reach the Master Degree. The experimental work was performed in the Discipline of Immunology of the Parasitology, Microbiology, and Immunology Department of UNIFESP-EPM.

2. Master Degree in Recovering Plastic Surgery and Post-Graduation at Doctor level by the Post-Graduation Program of Recovering Plastic Surgery of UNIFESP-EPM.

3. Titular Professor and Head of the Discipline Plastic Surgery of the UNIFESP-EPM Surgery Department, and Coordinator of the Post-Graduation Program for Recovering Plastic Surgery of UNIFESP-EPM.

Medical Doctor of UNIFESP-EPM.

Titular Professor of the Biomedical Sciences Institute of São Paulo University Immunology Department, Titular Professor of the Pathology Department of Veterinary Medical and Zootechnical School of USP, and Visitor Professor of the Discipline Immunology in the Parasitology, Microbiology, and Immunology of UNIFESPEPM.
} 
These models reached the preference of the global medical literature as experimental animals, to study heterologous grafts ${ }^{1}$ instead of animals undergone to neonatal thymectomy or chemical immunosupression in spite of their weaknesses.

However, due to their partial or total immunodeficiency, these models demand, for maintaining them, a laboratory infrastructure of sound environmental asepsis, as well as alimentary and operational special care. ${ }^{2}$ Nevertheless, these experimental models present high rates of morbidity and mortality. Said demands may also impair the models for some types of studies, or even, be very expensive or not viable for many investigators. ${ }^{3}$

The hamster (Mesocricetus auratus) is an experimental animal with a natural Immunologically Privileged Site placed in the sub-epithelium of a pouch exisiting at both sides of the oral cavity. Conceptually, an immunologically privileged site would result from the absence or deficiency of a suitable afferent anatomical pathway to drain antigenetic material to a regional lymphatic station, whose presence would recognize the antigen and would start the immune response. ${ }^{4}$

The species Mesocricetus auratus is also known as golden Syrian hamster or Lebanese squirrel because its origin is a region in the North of Syria, near the Euphrates River, named Aleppo. The Syrian golden hamster was described in 1839 and by unknown reason, in the beginning of the 20th Century, it was considered as being extinct. In 1930, Professor Aharoni of Jerusalem Hebraic University collected in Aleppo one female and its 12 broods. After one year of breeding, some from this strain specimens were sent to the United Kingdom in 1931 and to the United States in 1938. The species adpated easily to Western countries and became the most common amongst all the hamsters. Nowadays, all the exisiting animals of the species are descendants from that strain breeded in Jerusalem. ${ }^{5}$ The Chinese hamster (Cricetulus griseus) was already used in China as common experimental model since 1919. The Syrian golden hamster, however, was only explored as a model carrier of an immunologic privilege site from the middle of the 40 s.

The decades 1960, 1970 up to approximately 1985 represented the apex period of researches in medical literature, using the hamster cheek pouch, a trend which was afterwards substituted for the use of animals coming from Bioegineering.

\section{Proposition}

Hamster's cheek pouch sub-epithelium may be indicated for studying grafts of benign cutaneous diseases, such as: nevus, warts, seborrheic keratosis, sebum hyperplasia, xanthomas, angiomas, dermatofibromas and malignant neoplasias as basocellular and spinocellular carcinoma ${ }^{6}$, and cutaneous melanoma. ${ }^{(7)}$ In the same way, the hamster cheek pouch may also be indicated for chemotherapeutic ${ }^{7}$ drugs action and qualification tests, besides identification of carcinogenic substances. ${ }^{8}$

Due to the transparency of the epithelium and to its rich vascularization, hamster cheek pouch may be used as a model for performing angiogenesis studies with cutaneous tissues, ${ }^{6,9}$ to biochemical studies in both inflammatory and allergic reactions, ${ }^{10}$ as well as for in vivo evaluation of dynamics of the microcirculation. ${ }^{11}$ The cheek pouch may also be useful for researches on infectious and parasitary cutaneous diseases. ${ }^{12}$

This study purpose is both standardize and analyze hamster cheek pouch as an integration experimental model for human skin heterologous grafts.

\section{Model description}

Hamster cheek or jugal pouches are highly distensible diverticles or bilateral sack invaginations of the jugal mucosas. They are extended under the skin from the posterior border of the oral cavity to about the scapulas of the animal. The main function of these pouches is storing and transporting food. In females, specifically, they also serve to transport broots in case of perceived danger ("hamstern", in German, means "to catch"). The way for emptying the content of the pouch is the contraction of the pouch retractor muscle (FIGURE 1). 

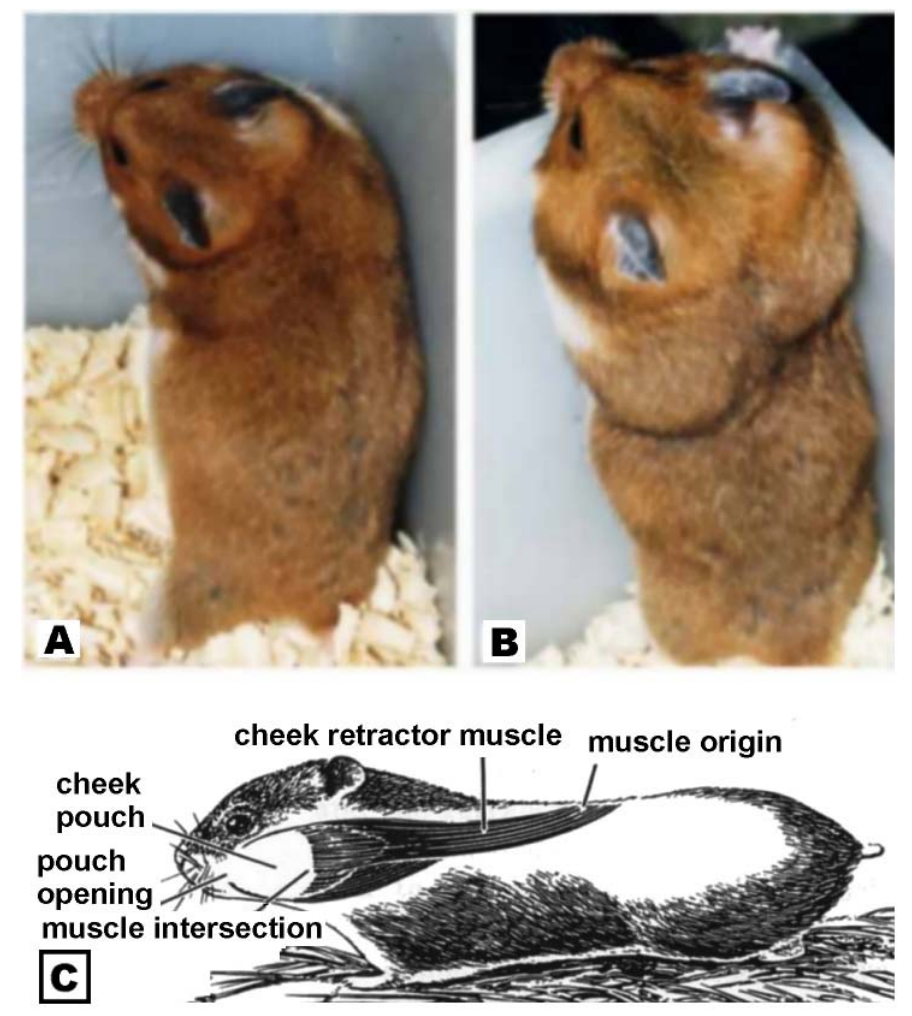

FIGURE 1 - Syrian golden hamster (Mesocricetus auratus). A - Animal with empty cheek pouches.

B - Cheek pouches with food to be carried out.

$\mathrm{C}$ - Scheme of the anatomical disposition of cheek pouch and pouch retractor muscle in hamster.

Each pouch, after being everted, presents two walls or epithelium layers. Each layer is formed by epithelial cells strata, which are sustained on areolar conjunctive tissue, without lymphatic vases, ${ }^{13}$ excepting amongst the pouch retractor muscle fibers of insertion. ${ }^{14}$ Therefore, this virtual space between both epithelial walls constitutes the cheek pouch sub-epithelial space which is naturally immunodeficient. Regional drainage lymphatic station of each pouch sub-epithelium woyld be, theoretically, the surface cervical regional lymphonode. ${ }^{12,15}$ Pouch wall epithelium ultra-structure is similar to the human skin, and has been named "skin without follicles and glands",16 and "richely vascularized pouch skin". It presents spiny, granular and corneous basal layer with keratinocytes, similar to the epidermis and gums epithelium or hard palate of humans. ${ }^{17,18}$ Besides the absence of annexial structures, the hamster cheek pouch is also without pigmentation. The vascular supply of hamster cheek pouches is performed by superior, mean and inferior sac arteries, which are branches of inferior labial artery. All this vascular complex is linked by plenty of arterial and venous anastomosis, which stil links, under the mandible, both pouches. Thus, this model of blood supply brings an anatomic subsidy which assures, from a vascular point of view, the integration and the growth of grafted tissues on any part of the pouch (FIGURE 2). 

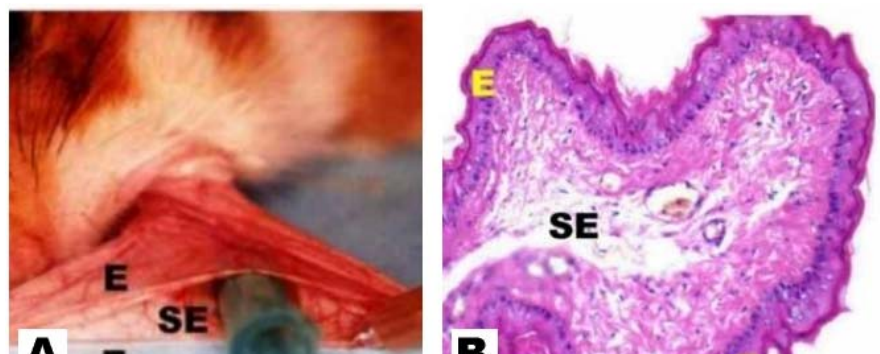

A
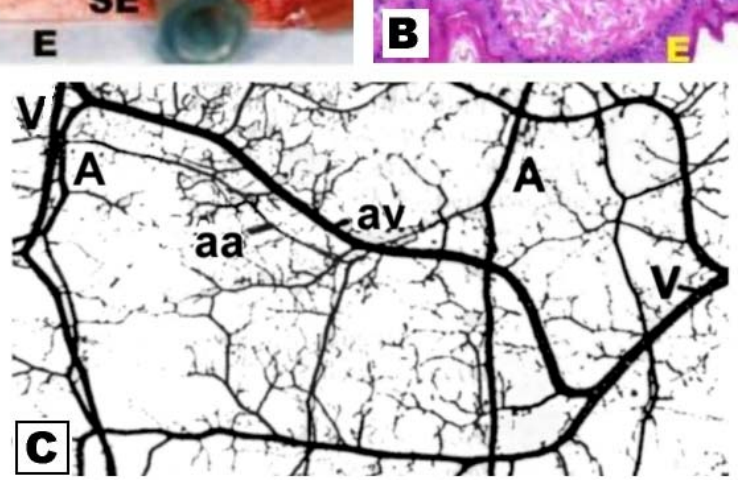

FIGURE 2 - Layers of hamster cheek pouch: macro- and microscopic aspects.

A - Demonstrative dissection of everted cheek pouches layers.

B - Microscopy of hamster cheek pouch layer in a sagital section (H.E. x 200).

C - Vascular aspect of hamster cheek pouch after contrast injection, evidencing a rich network of arterial and venous anastomosis [Figure obtained in the article: Poor E, Lutz BR. Anat Rec 1958;132(2):121-6].

[E = Pouch epithelium; $\mathrm{SE}=$ Subepihelium; $\mathrm{TC}=$ Conjunctive tissue; $\mathrm{M}=$ Pouch retractor muscle; $\mathrm{A}=$ Artery; $\mathrm{V}=$ Vein; aa = arterial anastomosis; $\mathrm{av}=$ venous anastomosis].

\section{Operation technique}

Cutaneous tissues to be grafted are obtained from exceeding operatory pieces which are posteriorly undergone to defatting procedure. They have to be transported from the surgical suite to the experimental laboratory immerse into a flask with physiologic solution at $0.9 \%$ into a covered styrofoam container with ice. Tissue fragments are obtained from a $2 \mathrm{~mm}$ circular punch and should remain until the moment of the graft insertion also immerged into chilled physiological solution.

Animals are preferably anesthetized via intraperitoneal. The combination of hydrochloride of 2(2,6-xylidine)-5,6-dihydro-4H-1,3-tiazine $\left(\right.$ Rompun $^{\circledR}$ ) (hypnotic) at a dose of $0.1 \mathrm{~mL} / \mathrm{kg}$ and ketamine hydrochloride (Francotar ${ }^{\circledR}$ ) (myorelaxing) at a dose of $0.075 \mathrm{~mL} / \mathrm{kg}$ is recommended. With the animal under anesthetic induction, in order to remove residuals from the cheek pouches, they are washed through gentle water jets injected from a syringe by the oral cavity, with the head of the animal positioned below the rest of its body to avoid accidental water inhalation.

Then, each pouch is everted with the help of two Adson-Brown forceps on styropor foam and it is fixed on it with $13 \times 4.5$ needles. Traction with the same forceps the proximal area of pouch epithelium by an avascular site, and with straight iris scissors a $5 \mathrm{~mm}$ incision is made. Through this incision, with the scissors, a rhombic divulsion of sub-epithelial tissue, in tunnel, to the most distal extremity of the pouch. With a narrow and long pincer the cutaneous tissue to be grafted is placed at the distal extremity of the disected tunnel. The pincer is removed while the fragment is grasped with a finger. Incision borders are approximated only by manoeuvre of bi-digital coaptation without the need of sutures. Finally, the needles are removed and the pouch is reintroduced into the oral cavity (FIGURE 3). Procedures may be performed without the conventional rigors of sepsis and antisepsis. 

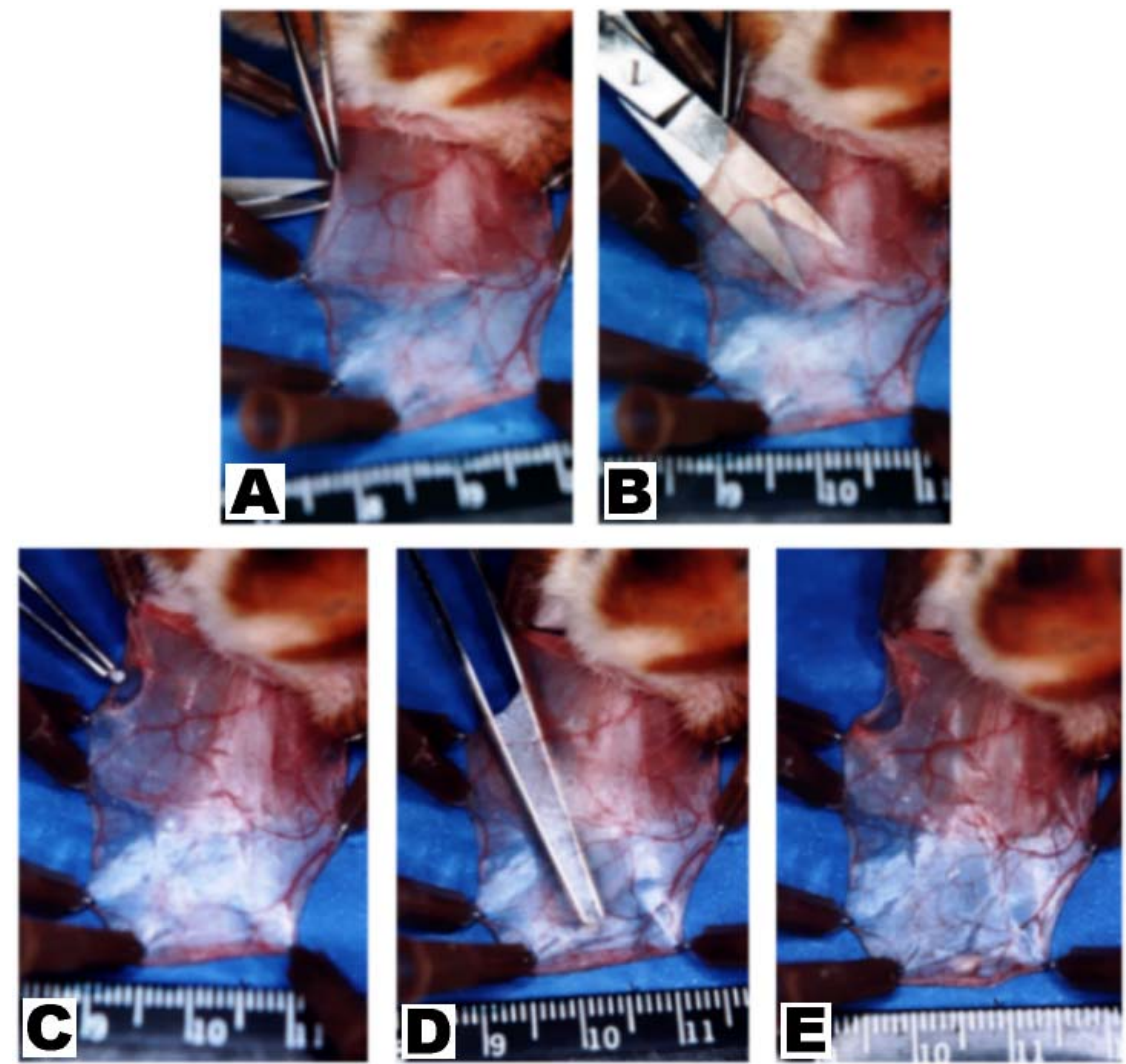

FIGURE 3 - Technique of grafting on hamster cheek pouch.

A - Everted and fixed on styropor cheek pouch, tracioning avascular area of epithelium, proximal to the animal's mouth where the incision will be performed.

B - Rhombic divulsion, in tunnel, from sub-epithelium to the distal site of the pouch.

C - Indroduction, by the incision, of the fragment to be grafted.

$\mathrm{D}$ - Positioning of the fragment to be grafted in the sub-epithelium of distal site of the pouch.

E - Final aspect of the hamster pouch with grafted fragment of human cutaneous tissue.

At the end of the pre-established time of grafting, animals are anesthetized again, pouches are resected and then animals are undergone euthanasia. These pouches are distended with needles on a styropor piece, and the grafted fragment site is marked with needle, in justadistal position, before the piece is immerged in $12 \%$ formaldehyde for fixing. This tactic aims to make easy its location within the pouch to histopathologic test, since after formaldehyde immersion the fragment may have difficult macroscopical enhancement. It is recommended that this marker needle is put at the longest ax (logitudinal) of the grafted fragment, with the aim of directing the laboratory technician and making easy the epithelium and conjunctive tissue inclusion on the glass plate to be examined (FIGURE 4). 


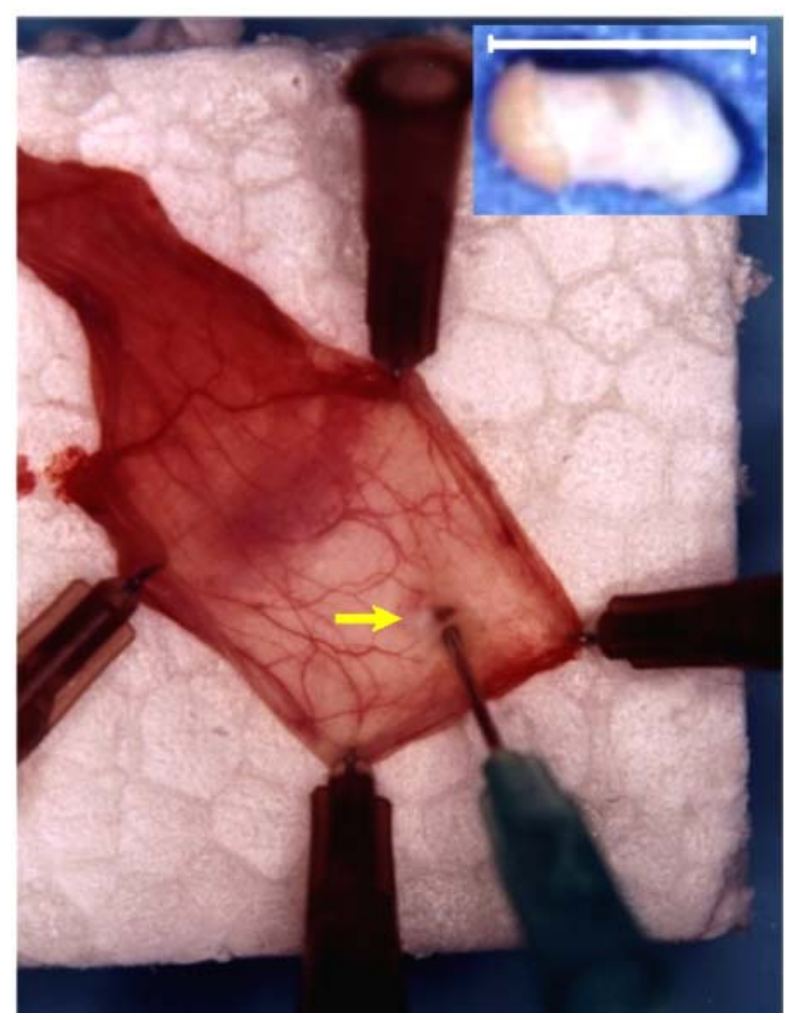

Figure 4 - Preparation of the pouch for histopathological examination.

After distending the pouch with needles on the styropor piece, the position of the grafted fragment is marked with a needle different of others (arrow), at distal position, before the graft is undergone formaldehyde. In the detail above, with a white line, the longest ax of the fragment is represented before it is grafted, enfolding epithelium and conjunctive tissue of cutaneous tissue (in this case, keloid).

\section{Advantages of the model}

This is a larger animal than mice, it is easily adapted to captivity, it is more gentle and capable of domestication, with easier operational handling. Unlike immunodepressed animals, hamsters can be fed with common water and food without needing laboratories and bioteries with special infrastrucutre. Only needed basic conditions of environmental basic hygiene with a cheap operational management are needed, which is accessible to researchers, in general. ${ }^{3}$ Morbidity and post-surgical complications rate in grafting is lower than $5 \%$, including conditions where asepsis rules are not followed.

At operatory level, the model presents easy access to pouch sub-epithelium by simple eversion manoeveur; disection is easy due to the pouch translucence, which means a low surgical trauma, hides grafted fragments and protect them from trauma, exempts from protective bands with no need of insulating each animal.

In skin fragments grafts, scars and cutaneous diseases in the cheek pouch of hamster, there is no need of de-epitelizing the fragment. In other experimental models, as athymic mice, this procedure is generally needed, with the purpose of avoiding inclusion cysts, since the transplant is performed on subcutaneous cellular tissue of the animal. Epithelium preservation, besides making easy the operatory act, enhances researches results (FIGURE 5). 

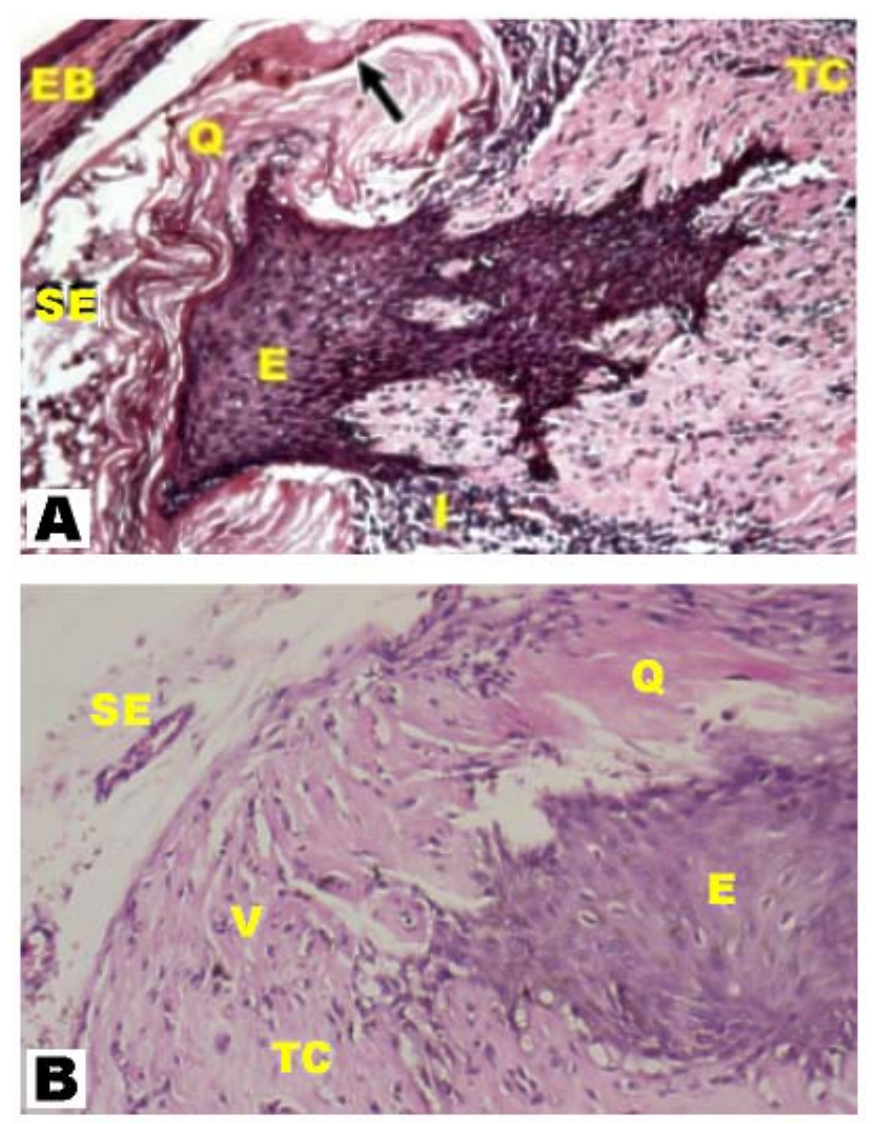

FIGURE 5 - Microscopic aspect of human skin fragment at 12 days and keloid at 21 days in hamster cheek pouch.

A - Integration and viability of grafted fragment is noted by the active keratin production by the epithelium, with 12 days after grafting, in the pouch sub-epithelium (arrow). (Color HE, x 200).

B - Grafted and integrated keloid fragment at 21 days (Color HE, x 200).

[EB = Pouch epithelium; $\mathrm{SE}=$ Pouch sub-epithelium; $\mathrm{E}=$ Epithelium of grafted fragment; $\mathrm{Q}=$ Keratin; $\mathrm{V}=$ Blood vase; $\mathrm{I}=$ Inflammatory infiltrated; TC = Graft conjunctive tissue].

Hamster cheek pouch epithelium have a similar ultra-structure than human skin and, more specifically, similar to the epidermis or epithelium of human gum or hard palate, ${ }^{17,18}$ and so it is also named "skin without follicles and glands"16 and "richly pouch vascularized skin". ${ }^{4}$ It has basal, spiny, granulous, and corneal layers with keratinocytes, while the mouse skin only has 2 or 3 layers. Thus, mouse granulous layer is different in human being because granules are not intra-cellular. Cheek pouches also present a rich perivascular network of mastocytes and, similarly the human being, without serotonin secretion, while mice mastocytes secrete significantly serotonin. ${ }^{10}$

Since the hamster has thymus and normal immunity, the risk of mice or transplanted immunodepressed mutant rats is avoided in more prolonged studies of developing immunity, mechanisms of rejection by producing $\mathrm{T}$ lymphocytes by extra-thymic vias, when they become older.Thus, the hamsters, because they have intact immune system, do not have naturally hormonal dysfunctions.

Therefore, all morphological and physiological similarities with the human being, above described, would reinforce that the hamster cheek pouch is an experimental model more suitable than dorsal subcutaneous cellular tissue of mice and rats, from the phylogenetic point of view, to perform human skin related researches. 


\section{Perspectives}

Hamster, as an experimental model, has peculiar characteristics that may represent a wide range of perspectives. As, for instance, the anatomical location and the immunological privilege of the animal cheek pouches maintain independence between each other, this is, the nature of the graft in a pouch does not have influence on the other side one, each pouch may be addressed and and approached as if it was a sub-unit of this experimental model. Therefore, if it is possible grafting tissues of different origins (organs) and donor source in each pouch (auto, homo, and heterologous grafts), it is possible indicating combinations in the same animal, be them auto-homo, auto-hetero, and hetero-heterologous grafts, as examples.

Because the hamster is an animal with qualified immune system, with sites of immunological privilege only in its cheek pouches, in the rest of its body it has entire afferent lymphatic vias, lymphonodes, and efferent vias. Therefore, vases are able to transport immune effectors from the synthesis sites to the target antigen. So, in case of previous antigenetic sensitivation by cutaneous heterologous grafts in any part of the body, excepting the cheek pouches, their sub-epithelium would lose the status of being an Immunologically Privileged Site for this determined heterologous graft. ${ }^{8}$

This characteristic would allow to indicate cross tests study with human skin antigens and keloid tissue, for example, with previously sensitized animals at one of these tissues.

Results could reveal either differences or analogies of antigenetic characteristics of each tissue obtained from the same individual. So, it could be possible to open a large screen of possibilities of immunological studies by following the current trend of researches.

It is possible grafting more than one fragment of the same tissue in each pouch, since the rich vascular network assures the survival of all the grafts in the pouch. This way, it is possible to multiply 2 ou 3-folds the amount of fragments obtained from each pouch, reaching a total of 4 or 6 fragments grafted at the same time in a same animal, with the suitable margin of separation between them. This situation could be demanded, for instance, where there is a need of a great amount of grafts, for certain studies (FIGURE 6).

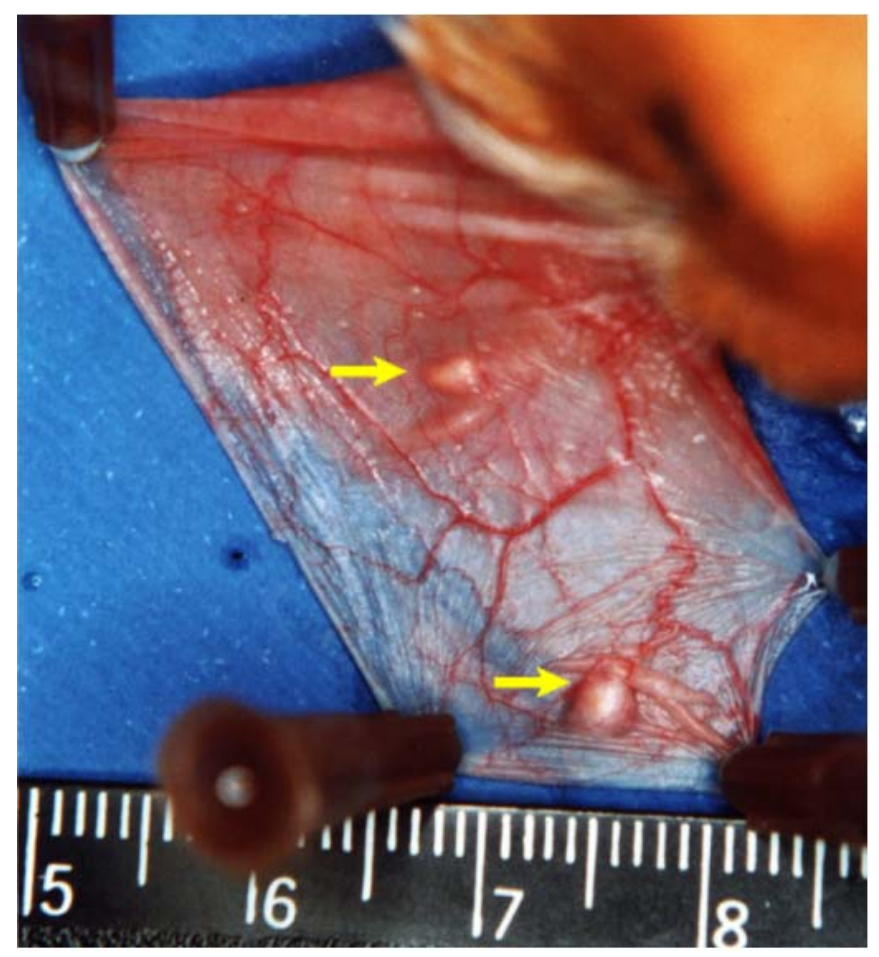

FIGURE 6 - Grafting of 2 fragments in the same cheek pouch. Macroscopic aspect at 21 days of two fragments of keloid in the same pouch (arrows). 
Immunobiology is still searching after an "ideal" experimental animal model to receive human skin heterologous grafts and related disturbs. Initially, this "ideal" model is described as an animal, which would have a small immunogenic potential but which would have excellent metabolic and physiologic compatibility with transplants coming from human beings. By all the above mentioned, characteristics, although researchers are still after this "ideal" animal, the authors may consider that the hamster would represent, a priori, a highly faithful and precise experimental model, over all other experimental small sized models, to study human cutaneous grafts ${ }^{18}$.

\section{References}

1.Thomas F, Araneda D, Henretta J, Pittman K, Marchman W - Extended and expanded studies of xenograft rejection in immunodeficient animals. Transplant Proc. 1994;26(3):1224-7.

2.Ferreira LM, Borsanyi JP, Benhaim P, Anthony JP, Mathes SJ, Andrews JM, Laredo Filho J - The incidence of lethal graft-versus-host disease in rat limb allotransplantations. Rev Hosp Sao Paulo-Esc Paul Med. 995;6(1/2):7-10.

3. Hochman B, Ferreira LM, Bôas FCV, Mariano M - Investigação do transplante heterólogo de quelóide na bolsa jugal do hamster (Mesocricetus auratus). Acta Cir Bras. 2003;18(4):266-71.

4.Head JR, Billingham RE - Immunologically privileged sites in transplantation immunology and oncology. Perspec Biol Med. 1985;29(1):115-31.

5.Adler S - Origin of the golden hamster Cricetus auratus as a laboratory animal. Nature. 1948;162:2567.

6.Wolf JE, Hubler WR - Tumor angiogenic factor and human skin tumors. Arch Dermatol. 1975;111:321

7.Dufour FD, Okada GT, Mah SG, Morton DL - Chemotherapy against human melanoma in the hamster cheek pouch. J Surg Oncol. 1980;15:355-61.

8.Ziegler MM, Lopez V, Barker CF - Carcinogenesis in an immunologically privileged site. J Surg Res. 1975;18:201-7.

9.Wolf J, Harrison RG - The angiogenic stimulus of epidermis and epidermal components on the microvasculature of the hamster cheek pouch. Bibl Anat. 1973;12:490-6.

10.Raud J, Dahlen SE, Smedegard G, Hedqvist P - An intravital microscopic model for mast celldependent inflammation in the hamster cheek pouch. Acta Physiol Scand. 1989;135:95-105.

11.Svensjo E, Bouskela E - Microcirculação na bolsa da bochecha do hamster. In: Castro e Silva Jr. O, Zucoloto S, Beer Jr. A - Modelos experimentais de pesquisa em cirurgia. Sao Paulo: Robe, 1998. p.795-02.

12.Arruda MSP, Montenegro MR - The hamster cheek pouch: an immunologically privileged site suitable to the study of granulomatous infections. Rev Inst Med Trop Sao Paulo. 1995;7(4):303-9.

13.Barker CF, Billinghan FRS - The lymphatic status of hamster cheek pouch tissue in relation to its properties as a graft and as a graft site. J Exp Med. 1971;133:620-39.

14.Goldenberg DM, Steinborn W - Reduced lymphatic drainage from hamster cheek pouch. Proc Soc Exp Bio Med. 1970;135:724-6.

15.Sinhorini IL, Merusse JLB, Mariano M - The role of lymphatic drainage on the development of BCGinduced granulomas in the hamster. Int Arch Allergy Immunol. 1994;103:166-74.

16.Duling BR - The preparation and use of the hamster cheek pouch for studies of the microcirculation. Microvasc Res. 1973;5:423-9.

17.White FH, Gohari K - Cellular and nuclear volumetric alterations during differentiation of normal hamster cheek pouch epithelium. Arch Dermatol Res. 1982;273:307-18.

18.Hochman B,Ferreira LM, Bôas FCV, Mariano M - Integração do enxerto heterólogo de pele humana no subepitélio da bolsa jugal do hamster (Mesocricetus auratus). Acta Cir Bras. 2003;18(5):415-30 
Hochman B, Ferreira LM, Vilas Bôas FC, Mariano M. Modelo experimental no hamster (Mesocricetus auratus) para estudo de transplantes heterólogos de cicatrizes e doenças cutâneas em cirurgia plástica. Acta Cir Bras [serial online] 2004 Vol 19 Edição Especial. Disponível em URL: http://www.scielo.br/acb.

RESUMO: O hamster sírio dourado (Mesocricetus auratus) possui no subepitélio de suas bolsas jugais um "Local de Privilégio Imunológico", permitindo a integração de homo e heteroenxertos. Este artigo descreve as características anatômicas e histológicas desse local, assim como os aspectos relativos as suas propriedades imunológicas. Cita, também, as vantagens desse modelo experimental sobre outros modelos portadores, naturais ou induzidos, de imunodeficiência. Com base nessas vantagens, e também baseado na literatura, tem o intuito de estabelecer esse modelo, mediante a realização de heteroenxertos, como uma outra opção para investigar distúrbios cicatriciais, como o quelóide, e doenças de interesse em Cirurgia Plástica, como lesões cutâneas benignas e neoplasias malignas como carcinomas e melanoma cutâneo. Tece, ainda, considerações sobre perspectivas de aplicações desse modelo, ainda bastante desconhecido entre a classe médica brasileira.

DESCRITORES: Mesocricetus. Transplante heterólogo. Transplante de pele. Quelóide.

Conflito de interesse: nenhum Fonte de financiamento: CAPES

\section{Correspondence:}

Dr. Bernardo Hochman

UNIFESP-EPM, Plastic Surgery Division, Surgery Division

Rua Napoleão de Barros, 715, $4^{\circ}$ andar.

CEP 04024-900 São Paulo

Tel: (11)55760418 FAX: (11) 55716579

sandra.dcir@epm.br

lydia.dcir@epm.br 